\title{
Incidence of leukaemia and other cancers in birth and schools cohorts in the Dounreay area
}

\author{
Roger J Black, James D Urquhart, Stephen W Kendrick, Kathryn J Bunch, Jan Warner, \\ David Adams Jones
}

\begin{abstract}
Objective-To determine whether a raised incidence of leukaemia in the Dounreay area occurred in children born to local mothers (birth cohort) or in those who moved to the area after birth (schools cohort) and also whether any cases of cancer have occurred in children born near Dounreay who may have moved elsewhere.

Design-Follow up study.

Setting-Dounreay area of Caithness, Scotland.

Subjects -4144 children born in the area in the period 1969-88 and 1641 children who attended local schools in the same period but who had been born elsewhere.

Main outcome measures-Cancer registration records linked to birth and schools records with computerised probability matching methods.

Results-Five cancer registrations were traced from the birth cohort compared with 5.8 expected on the basis of national rates (observed to expected ratio $0 \cdot 9,95 \%$ confidence interval $0 \cdot 3$ to $2 \cdot 0$ ). All five cases were of leukaemia $(2.3,0.7$ to 5.4$)$. In the schools cohort three cases were found $(2 \cdot 1,0.4$ to $6 \cdot 2$ ), all of which were of leukaemia $(6 \cdot 7,1.4$ to 19.5). All eight children were resident in the Dounreay area at the time of diagnosis; thus no cases were found in children who were born in or had attended school in the study area but who subsequently moved away.

Conclusion - The raised incidence of leukaemia in both the birth and schools cohorts suggests that place of birth is not a more important factor than place of residence in the series of cases of leukaemia observed near Dounreay area.
\end{abstract}

Scottish Health Service Common Services Agency, Information and Statistics Division, Edinburgh EH5 350

Roger J Black, senior research officer

James D Urquhart, senior principal research officer Stephen W Kendrick, senior health information scientist Jan Warner, cancer registration coordinator David Adams Jones, statistician

Childhood Cancer Research Group, University of Oxford, Oxford OX2 6HJ

Kathryn J Bunch, statistician

Correspondence to: $\mathrm{Mr}$ Black.

BMF 1992;304:1401-5
Dounreay who may have moved elsewhere. This paper reports the results of an investigation of cancer incidence in birth and schools cohorts in the Dounreay area, carried out in response to the second COMARE recommendation.

The sequence of investigation described above mirrors very closely that already undertaken in relation to the Sellafield nuclear fuel reprocessing plant in West Cumbria. Indeed, the rationale and aims of the present study are identical to those described by Gardner $e t a l$ in two papers reporting studies of birth and schools cohorts in Seascale, a civil parish near the Sellafield plant. ${ }^{67}$ Gardner et al pointed to two methodological weaknesses in earlier studies of cancer incidence and mortality in the Sellafield area ${ }^{89}$ that also apply to the Dounreay incidence studies. Firstly, in conventional geographical analyses of disease incidence the person years for the risk of contracting the disease in the area of interest are estimated either from population estimates for large administrative areas or, if these are not available, by interpolation of census counts between census years. In the Dounreay studies the interpolation method was used. However, population estimates derived in this way cannot take account of variations in the local birth rate that might influence the person years at risk in young age groups. Furthermore, the Dounreay area has been shown to have experienced rapid demographic change in the 1960s. ${ }^{10}$ Large numbers of young families settling in an area in a relatively short period of time might result in an unusual or unstable pattern of births. The cohort (follow up) approach overcomes these potential problems by linking incident cases directly to population denominators. Secondly, the earlier Dounreay studies were based on children's places of residence at the time of diagnosis. This means that cases that might have been diagnosed in children who moved from the area were not included in calculating the local incidence of leukaemia. Conversely, cases in children moving to the Dounreay area before diagnosis would have been included.

The Seascale cohort studies showed that the excess leukaemia mortality in children resident in the parish had occurred mainly in those who were also born there. ${ }^{67}$ More recent evidence from the case control study of leukaemia in West Cumbria suggests that the excess incidence of childhood leukaemia in Seascale might be explained by occupational exposures of fathers to radiation in the period immediately before conception. ${ }^{11}$ Taken together, these observations suggest that place of birth might be more important than place of residence at the time of diagnosis in the aetiology of childhood leukaemia. The cohort approach used in this study addresses the question of place of birth by treating as two distinct groups those born in the Dounreay area and those who attended school there, having been born elsewhere. 
The Sellafield and Dounreay sites differ from most other nuclear installations in that both are involved in reprocessing spent nuclear fuel. Although there are important differences in levels of discharges to the environment, the similarity of the plants' operations has been interpreted as potentially important in attempting to reach an explanation for the higher than expected incidence of leukaemia observed near both sites. This paper aims to present an analysis of cancer incidence in birth and schools cohorts in the Dounreay area which, within the constraints of the availability of basic data, is comparable with the Seascale cohort studies.

\section{Methods}

\section{SCHOOL RECORDS}

The Dounreay site became operational in 1958. The original intention of the study was to seek school records of children born from 1958 who attended primary schools in the area. In defining schools to be included in the study, those in the parishes of Reay, Halkirk, Thurso, Olrig, and Bower were chosen because, firstly, the geography of these areas approximates to the $25 \mathrm{~km}$ zone around the Dounreay site analysed by COMARE ${ }^{4}$; secondly, birth records in Scotland are organised in registration districts which, in the Caithness area, are coterminous with parishes; and, thirdly, the parishes chosen form the western district as defined by Caithness County Council's education department in the period up to 1974 . With the assistance of Highland Regional Council's education department, 16 primary schools that could have admitted pupils born since 1958 were identified (table 1).

In general the availability of admission records depended on whether or not schools had remained open after local government reorganisation in 1974. Inquiries were made at the Caithness district office of Highland Regional Council's education department in Wick, the regional council headquarters in Inverness,

TABLE I-Schools in Dounreay area admitting children born since 1958

\begin{tabular}{|c|c|c|c|c|}
\hline Parish & School & Year opened & Year closed & Records available \\
\hline \multirow[t]{2}{*}{ Reay } & Dounreay & & 1968 & Yes \\
\hline & Reay & 1968 & & Yes \\
\hline \multirow{5}{*}{ Halkirk } & Scotscalder & & 1962 & No \\
\hline & Spittal & & 1970 & No \\
\hline & Halkirk & & & Yes \\
\hline & Altnabreac & & 1978 & No \\
\hline & Lieurary & 1978 & & Yes \\
\hline \multirow[t]{6}{*}{ Thurso } & West Public & & 1967 & No \\
\hline & Janetstown & & 1970 & No \\
\hline & Weydale & & 1968 & No \\
\hline & Miller Academy & & & Yes \\
\hline & Pennyland & 1962 & & Yes \\
\hline & Mount Pleasant & & & Yes \\
\hline \multirow[t]{2}{*}{ Olrig } & Murkle & & 1970 & No \\
\hline & Castletown & & & Yes \\
\hline Bower & Bower & & & No \\
\hline
\end{tabular}

TABLE II -Numbers of children born in the period 1969-88 admitted to primary schools in the Dounreay area

\begin{tabular}{lc}
\hline School & $\begin{array}{c}\text { No of } \\
\text { admissions }\end{array}$ \\
\hline Reay & 161 \\
Halkirk & 458 \\
Lieurary & 260 \\
Miller Academy & 1355 \\
Pennyland & 1203 \\
Mount Pleasant & 936 \\
Castletown & 510 \\
\hline Total & 4883 \\
\hline
\end{tabular}

^ Annual school rolls rather than admission books obtained. the regional archivist, local libraries, and public offices in an attempt to trace the admission records of schools closed before 1974. In addition, retired head teachers and county council officials were approached. These inquiries were unsuccessful and a reassessment of the feasibility of the study was made. It was decided to limit the study to children born since 1969 as, firstly, computer records of births in Scotland were available from 1969 and, secondly, complete coverage of school records for the study area was available only from 1971 (table I). It was thought to be important to achieve complete coverage of school records for a defined area so that children could be allocated to the appropriate cohorts. This reduced the number of potentially relevant schools to nine: Reay, Halkirk, Altnabreac, Lieurary, Miller Academy, Pennyland, Mount

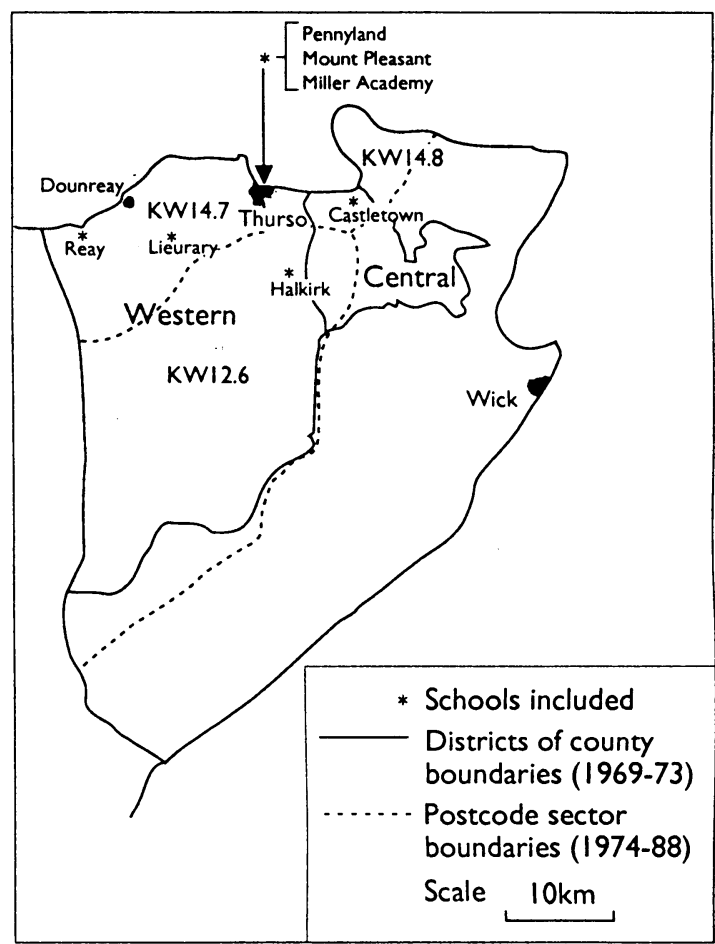

Study area and locations of schools from which records were obtained

Pleasant, Castletown, and Bower. Of these, Bower and Altnabreac were excluded because they serve populations that are largely outside the $25 \mathrm{~km}$ zone around Dounreay. Admission records were available for the remaining seven schools.

Permission to extract identifying information from the records was sought from head teachers and this was granted in every case. The figure shows the boundaries of the areas chosen for analysis and the locations of the schools included in the study. Children's full names (including second forenames and alternative surnames where recorded), sex, date of birth, and year of admission to school were keyed directly from photocopies of admission books for the period up to the end of 1988 . These records were then verified and checked clerically in preparation for data analysis. Table II shows the numbers of admissions to each school.

\section{BIRTH RECORDS}

Registrations of births in Scotland are held by the General Register Office (Scotland) in the form of computer records from 1969. Before 1974 births were required to be registered in the registration district in which they occurred. Thereafter births could be registered at any office, often the nearest to a mother's usual place of residence. However, Scottish birth records contain allocation codes indicating mother's usual place of residence. These are based on districts of county and small burghs before 1974 and postcodes thereafter. Thus the general registrar office was able to supply a listing of births to mothers resident in the study area from which the child's full name, sex, date of birth, registration district, and entry number were abstracted. Table III shows numbers of births ascertained in each of the study areas.

\section{DATA LINKAGE}

For allocating children to the birth or schools cohorts, the school admission records and the birth records were linked by using computerised probability matching techniques. The matching algorithms were based on techniques developed by the Oxford Record Linkage System ${ }^{12}$ and Statistics Canada ${ }^{13}$ and were part of an extensive programme of medical record linkage being carried out in the Common Services Agency of the Scottish Health Service. In addition, the results of 
the linkage were manually checked at each stage of the procedure. In a preliminary phase, the school records were linked internally to identify multiple entries for individual children which occurred, for example, where children had moved from one school to another. This linkage reduced the 4883 admission records to 3976 identifiable individuals. For 34 children either the date of birth or the sex was unknown and these records were excluded. The remaining 3942 records of identified school pupils were then linked with the birth records and 2301 were found to have been born in the study area, leaving a cohort of 1641 children who attended primary school in the study area, having been born elsewhere (the schools cohort). The birth cohort was made up of all children born in the study period from 1969 to 1988, including the 2301 who subsequently attended local schools. Table IV summarises the allocation of children to the two cohorts.

The Scottish national cancer registration scheme, administered by the Common Services Agency, holds records collected by five regional registries since 1959 . Registrations of leukaemia in the 0-24 age group in the period 1968-81 have been reviewed and amended in a validation exercise ${ }^{14}$ and the ascertainment rate and accuracy of data for this disease in more recent years is thought to be high. ${ }^{1}$ For other childhood cancers, incidences calculated from Scottish cancer registration data are comparable with those of England and Wales and other northern European countries. The ascertainment rate is thought to be over $90 \% .{ }^{15}$ A file of registrations up to 31 December 1988 of cancers in those born since 1969 was extracted from the national data set. This was then linked with the birth and schools records by using the probability weighted matching procedures already described. All potential links were checked by tracing the manual records held at the regional registries and, if necessary, by referring to hospital notes. To verify the results of this linkage exercise and to attempt to ascertain cases that might have been registered outside Scotland, the birth and schools records were also linked with data held by the National Registry of Childhood Tumours. ${ }^{16}$

\section{ANALYSIS}

Expected numbers of cases were calculated by the allocation of person years at risk based on Scottish

TABLE III - Numbers of births to mothers resident in the Dounreay area, by area of residence and period of birth, 1969-88

\begin{tabular}{lccr}
\hline & \multicolumn{2}{c}{ Period of birth } & \\
\cline { 2 - 3 } Area & $1969-73$ & $1974-88$ & \multirow{2}{*}{ Total } \\
\hline Thurso small burgh & 756 & & 756 \\
Western district (of Caithness County) & 247 & & 247 \\
Central district (of Caithness County) & 147 & 1568 & 1568 \\
KW14.7 postcode sector & & 1144 & 1144 \\
KW 14.8 postcode sector & & 282 & 282 \\
KW12.6 postcode sector & & 2994 & 4144 \\
\hline Total & 1150 & 290 \\
\hline
\end{tabular}

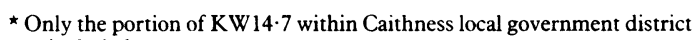
was included.

TABLE IV-Numbers of children allocated to birth and school cohorts by period of birth and school of firs admission

\begin{tabular}{|c|c|c|c|c|c|}
\hline & \multicolumn{4}{|c|}{ Period of birth } & \multirow[b]{2}{*}{ Total } \\
\hline & $1969-73$ & $1974-78$ & $1979-83$ & $1984-88$ & \\
\hline Birth cohort & 1150 & 996 & 1077 & 951 & 4144 \\
\hline Schools cohort: & 778 & 511 & 340 & 12 & 1641 \\
\hline Reay & 36 & 13 & 12 & & 61 \\
\hline Halkirk & 51 & 45 & 43 & 1 & 140 \\
\hline Lieurary & 2 & 2 & 2 & & 6 \\
\hline Miller Academy & 247 & 181 & 105 & 1 & 534 \\
\hline Mount Pleasant & 77 & 58 & 48 & 9 & 192 \\
\hline Pennyland & 272 & 166 & 95 & 1 & 534 \\
\hline Castletown & 93 & 46 & 35 & & 174 \\
\hline
\end{tabular}

TABLE V-Numbers of children admitted to schools in the Dounreay area by cohort, period of admission, and age at admission

\begin{tabular}{lcc}
\hline & Birth cohort & Schools cohort \\
\hline Period of admission: & 1 & \\
$1969-73$ & 819 & 563 \\
$1974-78$ & 669 & 578 \\
$1975-83$ & 812 & 500 \\
$1984-88$ & & \\
Age at admission (years): & 268 & 48 \\
3 & 1115 & 435 \\
4 & 856 & 583 \\
5 & 21 & 153 \\
6 & 15 & 139 \\
7 & 12 & 109 \\
8 & 7 & 76 \\
9 & 2 & 67 \\
10 & 3 & 26 \\
11 & 2 & 5 \\
No admission record & 1843 & 1641 \\
\hline Total & 4144 & \\
\hline
\end{tabular}

TABLE VI-Numbers (and percentages of all births in area) of birth cohort children admitted to local schools by period of birth and area of residence at birth

\begin{tabular}{lcc}
\hline $\begin{array}{l}\text { Period of birth and area of } \\
\text { residence }\end{array}$ & No & $\begin{array}{c}\text { Percentage of all } \\
\text { births in area }\end{array}$ \\
\hline $\begin{array}{l}\text { No (\%) born 1969-73: } \\
\text { Thurso small burgh }\end{array}$ & 514 & 68 \\
Central district of county & 104 & 71 \\
Western district of county & 172 & 70 \\
No (\%) born 1974-83: & 743 & 68 \\
KW14.7 postcode sector & 531 & 71 \\
KW14.8 postcode sector & 169 & 83 \\
KW12.6 postcode sector & 2233 & 70 \\
\hline Total & & \\
\hline
\end{tabular}

national rates broken down by tumour site, sex, age, and calendar year of registration. For the birth cohort the person years at risk were allocated from the year of birth to the end of the study (31 December 1988) and for the schools cohort from the year of first admission to a local school to the end of the study. As no information on deaths or emigration was available no withdrawals were accounted for in calculating person years at risk. Results are expressed as ratios of observed to expected cases with Poisson based confidence intervals calculated by standard methods. ${ }^{17}$

\section{Results}

Table V shows a breakdown of year and age at first admission to schools in the study area for children allocated to the birth and schools cohorts. As might be expected from the pattern of births over time shown in table IV, the numbers of admissions to schools of children born in the study area fell from 819 in 1974-8 to 669 in $1979-83$ and rose again to 812 in $1984-8$. In the schools cohort the numbers of admissions over the period 1974-83 remained fairly constant at about 115 a year before falling to about 100 a year thereafter. A total of $1066(65 \%)$ children in the schools cohort first attended a school in the study area at or before the age of 5 .

Table VI shows the areas of residence at birth of the 2233 children who were born in the study area in the period 1969-83 and were admitted to local schools. The overall proportion $(70 \%)$ seems to be consistent between the areas and time periods considered. This implies a fairly constant outward movement before school age of about $30 \%$ of children born in the area. Children born in the last time period, 1984-8, have been excluded from this table as most would not have attained school age by the end of the study period.

In table VII the observed numbers of cancer registrations in the birth and schools cohorts are compared with expected numbers based on Scottish national 
rates. In the birth cohort five registrations were found compared with 5.8 expected (a ratio of $0.9 ; 95 \%$ confidence interval 0.3 to $2 \cdot 0$ ). All five cases were of leukaemia $(2 \cdot 3 ; 0.7$ to $5 \cdot 4)$. One case had originally been registered as non-Hodgkin's lymphoma and al were previously known to COMARE. ${ }^{4}$ All were resident in the Dounreay area at the time of diagnosis; thus no cases were found in children who were born in the study area but who subsequently moved away. In the schools cohort, three registrations were found where 1.4 would be expected from national rates $(2 \cdot 1$; 0.4 to $6 \cdot 2)$. Again, all the cases were of leukaemia $(6 \cdot 7$ $1 \cdot 4-19 \cdot 5)$. One case was included in the COMARE analysis. ${ }^{+}$COMARE was also aware of one other case, originally registered in 1986 as non-Hodgkin's lymphoma but considered by COMARE to be leukaemia, although not included in the principal analysis. The third case, of a boy aged 16 at diagnosis in 1988 , was previously unknown to COMARE. All three children were resident in the study area at the time of diagnosis. One child was born in Strathclyde region, the second in England, and the third in Highland region outside Caithness.

Table VIII shows that no particular pattern was evident in the years of birth or age at diagnosis of the

TABLE VII-Observed and expected registrations of malignant neoplasms (ICD 140-208) by tumour site and cohor

\begin{tabular}{|c|c|c|c|}
\hline Cohort and site & No observed $(\mathrm{O})$ & No expected $(E)$ & $\begin{array}{c}\mathrm{O} / \mathrm{E} \text { ratio } \\
(95 \% \text { confidence interval })\end{array}$ \\
\hline Birth cohort: & 5 & $5 \cdot 8$ & $0.9(0.3$ to 2.0$)$ \\
\hline Leukaemia and non-Hodgkin's lymphoma & 5 & $2 \cdot 2$ & $2 \cdot 3(0.7$ to 5.4$)$ \\
\hline Hodgkin's disease & & $0 \cdot 3$ & $0(0.0$ to $13 \cdot 8)$ \\
\hline Other cancers & & $3 \cdot 4$ & $0(0 \cdot 0$ to $1 \cdot 1)$ \\
\hline Schools cohort: & 3 & $1 \cdot 4$ & $2 \cdot 1(0 \cdot 4$ to $6 \cdot 2)$ \\
\hline Leukaemia and non-Hodgkin's lymphoma & 3 & $0 \cdot 4$ & $6.7(1.4$ to 19.5$)$ \\
\hline Hodgkin's disease & & $0 \cdot 2$ & $0(0 \cdot 0$ to $24 \cdot 2)$ \\
\hline Other cancers & & $0 \cdot 8$ & $0(0.0$ to $4 \cdot 5)$ \\
\hline
\end{tabular}

TABLE VIII-Observed and expected registrations of malignant neoplasms (ICD 140-208) by cohort, period of birth, age, sex, period of follow up, and school of first admission

$\mathrm{O} / \mathrm{E}$ ratio

No observed $(\mathrm{O})$ No expected $(\mathrm{E}) \quad(95 \%$ confidence interval $)$

\begin{tabular}{|c|c|c|c|}
\hline \multicolumn{4}{|c|}{ Birth cohort } \\
\hline \multicolumn{4}{|l|}{ Period of birth: } \\
\hline $1969-73$ & 1 & $2 \cdot 5$ & $0.4(0.1$ to $2 \cdot 2)$ \\
\hline $1974-78$ & 3 & 1.6 & $1.9(0.4$ to 5.6$)$ \\
\hline $1979-83$ & 1 & $1 \cdot 2$ & $0.8(0.0$ to 4.4$)$ \\
\hline $1984-88$ & & 0.5 & $0(0.0$ to $7 \cdot 1)$ \\
\hline \multicolumn{4}{|l|}{ Age: } \\
\hline 0 & & $0 \cdot 7$ & $0(0.0$ to 5.5$)$ \\
\hline $1-4$ & 3 & $2 \cdot 5$ & $1.2(0.3$ to 3.6$)$ \\
\hline $5-9$ & 2 & 1.4 & $1.4(0.2$ to 5.1$)$ \\
\hline $10-14$ & & $0 \cdot 7$ & $0(0.0$ to 5.2$)$ \\
\hline $15-19$ & & $0 \cdot 6$ & $0(0.0$ to 6.4$)$ \\
\hline \multicolumn{4}{|l|}{ Sex: } \\
\hline Male & 2 & $3 \cdot 3$ & $0.6(0 \cdot 1$ to $2 \cdot 2)$ \\
\hline Female & 3 & $2 \cdot 5$ & $1 \cdot 2(0.2$ to 3.5$)$ \\
\hline \multicolumn{4}{|l|}{ Period of follow up: } \\
\hline $1969-73$ & & $0 \cdot 5$ & $0(0 \cdot 0$ to $7 \cdot 3)$ \\
\hline $1974-78$ & & $1 \cdot 2$ & $0(0.0$ to 2.9$)$ \\
\hline $1979-83$ & 5 & $1 \cdot 7$ & $3.0(1.0$ to 7.0$)$ \\
\hline \multirow[t]{2}{*}{$1984-88$} & & $2 \cdot 4$ & $0(0.0$ to 1.5$)$ \\
\hline & Schools C & & \\
\hline \multicolumn{4}{|l|}{ Period of birth: } \\
\hline $1969-73$ & 2 & $1 \cdot 0$ & $2 \cdot 1(0.3$ to 7.5$)$ \\
\hline $1974-78$ & 1 & $0 \cdot 3$ & $2 \cdot 9(0 \cdot 1$ to $15 \cdot 9)$ \\
\hline $1979-83$ & & $0 \cdot 1$ & $0(0.0$ to $39 \cdot 1)$ \\
\hline \multicolumn{4}{|l|}{ Age: } \\
\hline $5-9$ & & $0 \cdot 5$ & $0(0.0$ to 6.7$)$ \\
\hline $10-14$ & 2 & 0.5 & $4.4(0.5$ to 15.9$)$ \\
\hline $15-19$ & 1 & 0.4 & $2.6(0.1$ to 14.5$)$ \\
\hline \multicolumn{4}{|l|}{ Sex: } \\
\hline Male & 1 & $0 \cdot 8$ & $1.2(0.4$ to 6.9$)$ \\
\hline Female & 2 & $0 \cdot 6$ & $3.3(0.4$ to 11.9$)$ \\
\hline \multicolumn{4}{|l|}{ Period of follow up: } \\
\hline $1974-78$ & & $0 \cdot 2$ & $0(0.0$ to 22.0$)$ \\
\hline $1979-83$ & 1 & $0 \cdot 4$ & $2 \cdot 4(0.1$ to $13 \cdot 5)$ \\
\hline $1984-88$ & 2 & $0 \cdot 8$ & $2 \cdot 4(0.3$ to $8 \cdot 7)$ \\
\hline \multicolumn{4}{|l|}{ School: } \\
\hline Reay & & $0 \cdot 1$ & $0(0.0$ to 60.0$)$ \\
\hline Halkirk & & $0 \cdot 1$ & $0(0.0$ to 36.4$)$ \\
\hline Lieurary & & 0 & $0(0.0$ to $>99.9)$ \\
\hline Miller Academy & 2 & 0.5 & $4.4(0.5$ to 15.9$)$ \\
\hline Mount Pleasant & & $0 \cdot 2$ & $0(0.0$ to 21.7$)$ \\
\hline Pennyland & 1 & 0.5 & $2 \cdot 1(0 \cdot 1$ to $24 \cdot 6)$ \\
\hline Castletown & & $0 \cdot 2$ & $0(0.0$ to 23.5$)$ \\
\hline
\end{tabular}

cases found in the birth cohort, but all five cases in the birth cohort were registered in 1979-83. In the schools cohort, the existence of only three cases means that it is unlikely that there would be any discernible patterns, but, as with the cases in the birth cohort, all three occurred after 1979. School of first admission was not of interest even when the schools attended by children in the birth cohort were considered. One of the five birth cohort children died before school age, two attended Pennyland school, and the remaining two attended Lieurary and Castletown schools.

\section{Discussion}

The first aim of this study was to consider whether the excess of registrations of leukaemia and nonHodgkin's lymphoma in children and young adults resident in the Dounreay area occurred in those born there or those who were born elsewhere. We have shown that the incidence of leukaemia and nonHodgkin's lymphoma was raised in both the birth and schools cohorts (observed to expected ratios of 2.3 and 6.7 respectively). The second main aim of the study was to attempt to ascertain cases of leukaemia, nonHodgkin's lymphoma, and other cancers in those born in the Dounreay area who might have moved elsewhere before being registered as cancer cases. No such cases were found.

A secondary intention in this study was to determine the incidence of leukaemia and non-Hodgkin's lymphoma in the Dounreay area on the basis of the exact allocation of person years at risk and the follow up method of ascertainment. Taken separately, the incidence of these diseases in the birth and schools cohorts studied is raised, but significantly so only in the schools cohort. Considered together, the observation of eight cases of leukaemia and non-Hodgkin's lymphoma compared with 2.6 expected on the basis of national rates $(3.0 ; 1.5$ to 5.5$)$ is not inconsistent with the eight cases of leukaemia and non-Hodgkin's lymphoma observed in the $25 \mathrm{~km}$ zone in the period 1968-84 compared with 3.9 expected $(2 \cdot 1 ; 1.0$ to $3 \cdot 7)$ reported by COMARE. ${ }^{+}$Thus, even though the mobility of the population at risk has been shown to be high, the incidence rates of leukaemia and nonHodgkin's lymphoma reported in the earlier geographical studies did not overestimate risk in the local population.

\section{CHOICE OF METHOD}

The similarities of the operations carried out at Sellafield and Dounreay, even though levels of discharges to the environment were greater at Sellafield, and the findings of raised leukaemia incidence near both sites lead inevitably to the need to consider the results reported here for the Dounreay area in the light of those reported by Gardner et al for Seascale. Important differences in the methodologies used in the two studies must, however, be considered. Ascertainment in the Seascale studies was by manual searches of the NHS central register, principally for notifications of death. In contrast, the present study used computerised methods to link school and birth records to cancer registration records. There were three main reasons for this choice of method. Firstly, the present study included many more subjects: 5785 compared with 2614 in the Seascale studies. Secondly, computerised birth and cancer registration records were available for the period for which school admission records were also available. Thirdly, the improving prognosis for many childhood cancer patients, particularly those with leukaemia (the five year survival rate in the 0-4 age group in Scotland in $1978-82$ was $53 \%$ ), means that incidence data are now a more reliable basis than mortality data for estimating the risk of these diseases. 
An advantage of using searches of the NHS central register is that emigrants and subjects dying from causes other than cancer can be withdrawn from the calculation of person years at risk of dying from cancer. No such adjustment was made in the present study. If the proportion of emigrants and deaths from other causes in the Seascale schools cohort study were to apply to the Dounreay area then the person years at risk would be overestimated by approximately $5 \%$. Overestimation of this order would not affect the interpretation and overall conclusions drawn from this study. In the Seascale studies, the success of the searches of the register in tracing all cases of leukaemia expected from earlier studies led the authors to express confidence in this method of ascertainment. In the present study, all cases anticipated on the basis of the COMARE investigation of the Dounreay area were found.

\section{CASE FINDING}

Of the eight cases described in the COMARE report in the $25 \mathrm{~km}$ zone around Dounreay in the period 1968-84, five were found in the birth cohort and one in the schools cohort. The remaining two cases were subjects born before 1969, the earliest year for which births were included. One had been born in England and the other in Caithnesss, within the area covered in the present study. Thus all cases expected in this study were found by the computerised record linkage method used. The range of values of the linkage scores (which are proportional to the probability that two linked records relate to the same individual) for those cases expected was 24.6 to $36 \cdot 6$, but any potential matches with scores of 10.0 or more were checked manually. Thus it is unlikely that the absence of any cancer registrations in subjects who move away from the Dounreay area could be an artefact of the method of ascertainment used.

Although an investigation of the levels of population mobility was not one of the aims of this study, the basic results obtained are broadly comparable with those from Seascale. Approximately $30 \%$ of children born in the Dounreay area did not attend schools there, compared with $43 \%$ in the Seascale studies. Of those assumed to have moved to the Dounreay area after birth, $65 \%$ did so before attaining school age compared with $60 \%$ in the Seascale studies.

\section{CONCLUSIONS}

The main finding of this study is the raised incidence of leukaemia and non-Hodgkin's lymphoma in both the birth and schools cohorts. Although the ratio of leukaemia mortality in the Seascale birth and schools cohorts was not significantly greater than unity, the finding that the majority of cases occurred in the birth cohort and the more recent results of the west Cumbria case control study ${ }^{11}$ focused attention on potential risk factors associated with place of birth rather than place of residence at the time of diagnosis of the cases of leukaemia found in the Seascale and Dounreay areas. The results of the present study and the previously reported case-control study ${ }^{5}$ suggest that place of birth is not a more important factor than place of residence at diagnosis in the series of cases of leukaemia and nonHodgkin's lymphoma observed in the Dounreay area. Furthermore, no important trends in the years of birth of the cases were found. In an analysis of periods of birth and diagnosis and of sex and age at diagnosis only the period of diagnosis seemed to be important. All eight cases of leukaemia were diagnosed after 1978, six of these in the period 1979-83. The most remarkable features of this series of cases in the Dounreay area remain their concentration in a relatively short period of time and the common diagnosis of leukaemia with a complete absence of all other types of childhood cancer.

We thank the General Register Office (Scotland) and in particular Miss Christine Rae and Mr Jack Arrundale for their valuable advice on birth records in Scotland; Highland Regional Council Education Department; and the head teachers of the schools in Caithness from which we sought admission records. We also thank the Office of Population Censuses and Surveys, the regional cancer registries, and the many organisations and individuals who contribute to the national cancer registers in Scotland and in England and Wales, and the National Registry of Childhood Tumours at the Childhood Cancer Research Group. We thank Mr Graeme Hunter, Miss Jill Morrison, Miss Antonia Romero, and other staff of Common Services Agency Information and Statistics Division involved in the collection and preparation of data. We are grateful to Professor M Bobrow, Dr G J Draper, and Professor M J Gardner, who kindly commented on an earlier version of the paper. The study was partially funded from a Scottish Home and Health Department grant. The Childhood Cancer Research Group is supported by the Department of Health and the Scottish Home and Health Department.

1 Heasman MA, Urquhart JD, Kemp IW, Black RJ. Childhood leukaemia in Northern Scotland. Lancet 1986; ; 266,385.

2 Heasman MA, Urquhart JD, Black RJ, Kemp IW, Glass S, Gray M Leukaemia in young persons in Scotland: a study of its geographical distribution and relationship to nuclear installations. Health Bulletin 1987; 45:147.

3 Bell AG. Report of the Dounreay EDRP public local inquiry relating to the planning application for the siting of the European Demonstration Plan (EDRP) for fast reactor fuel (Caithness, 7 April-25 November 1986). Edinburgh: Scottish Office, 1989.

4 Committee on Medical Aspects of Radiation in the Environment (COMARE). Second report. Investigation of the possible increased incidence of leukaemia in young people near the Dounreay nuclear establishment, Caithness, Scotland. Loundon: HMSO, 1988.

5 Urquhart JD, Black RJ, Muirhead MJ, Sharp L, Maxwell M, Eden OB, et al. Case-control study of leukaemia and non-Hodgkin's lymphoma in children in Caithness near the Dounreay nuclear installation. BMY 1991;302:687-92.

6 Gardner MJ, Hall AJ, Downes S, Terrell JD. Follow up study of children born elsewhere but attending schools in Seascale, West Cumbria (schools cohort). $B M \mathcal{F} 1987 ; 295: 819-22$

7 Gardner MJ, Hall AJ, Downes S, Terrell JD. Follow up study of children born to mothers resident in Seascale, West Cumbria (birth cohort). BMJ 1987;295:822-7.

8 Black D. Investigation of the possible increased incidence of cancer in West Cumbria. London: HMSO, 1984

9 Gardner MJ, Winter PD. Mortality in Cumberland during 1959-78 with reference to cancer in young people around Windscale. Lancet 1984;i:216-7.

10 Kinlen L. Evidence for an infective cause of childhood leukaemia: comparison of a Scottish new town with nuclear reprocessing sites in Britain. Lancet 1988;ii: 1323 .

11 Gardner MJ, Snee MP, Hall A, Powell CA, Downes S, Terrell JD. Results of a case-control study of leukaemia and lymphoma among young people near case-control study of leukaemia and lymphoma among young peop

12 Baldwin JA, Acheson ED, Graham WJ, eds. Textbook of medical record linkage. Oxford: Oxford University Press, 1987.

13 Newcombe HM. Handbook of record linkage. Oxford: Oxford University Press, 1988

14 Glass S, Gray M, Eden OB, Hann IM. Scottish validation study of cancer registration data for childhood leukaemia 1968-81. Leuk Res 1987;2:88

5 Stiller CA, Kemp I, Draper GJ, Fearnly H, Lennox EL, Roberts EM, et al. United Kingdom - Scotland: National Registry of Childhood Tumours, 1971-80. In: Parkin DM, Stiller CA, Draper GJ, Bieber CA, Terracini B, Young JL, eds. International incidence of childhood cancer. Lyon: International Agency for Research on Cancer, 1988. Scientific publication No 87.)

16 Draper GJ, Stiller CA, Fearnly H, Lennox EL, Roberts EM, Sanders BM. United Kindgom-England and Wales: National Registry of Childhood Tumours, 1971-80. In: Parkin DM, Stiller CA, Draper GJ, Bieber CA, Terracini B, Young JL, eds. International incidence of childhood cancir. Lyon: International Agency for Research on Cancer, 1988. (Scientific publication No 87 .

17 Breslow NE, Day NE. Statistical methods in cancer research. Vol II. The design and analysis of cohort studies. Lyon: International Agency for Research on Cancer, 1987. (Scientific publications No 82.)

(Accepted 20 March 1992) 